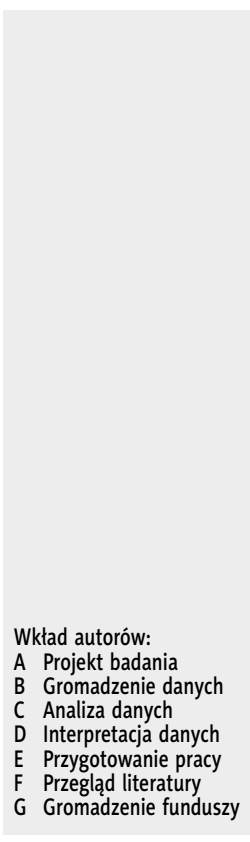

\title{
Rozwój mowy dziecka z zespołem wrodzonej centralnej hipowentylacji (CCHS): diagnoza, założenia i efekty terapii logopedycznej. Studium przypadku
}

\section{Speech and language development of a child with congenital central hypoventilation syndrome (CCHS) - diagnosis, guidelines and effects of speech therapy. A case study}

\author{
Karolina Samsonowicz ${ }^{\mathrm{ABCDEF}}$, Justyna Piniaha ${ }^{\mathrm{B}}$, \\ Anna Geremek-Samsonowicz ${ }^{\mathrm{DE}}$
}

Instytut Fizjologii i Patologii Słuchu, Światowe Centrum Słuchu, Warszawa/Kajetany

\begin{abstract}
Streszczenie
Praca przedstawia studium przypadku pacjenta w wieku 5 lat i 2 miesiące z zespołem wrodzonej centralnej hipowentylacji (CCHS) oraz tracheostomią. Jej celem jest omówienie przebiegu rozwoju mowy, założeń i efektów terapii logopedycznej u badanego dziecka. Przedstawiony przypadek ze względu na rzadko występującą chorobę, nietypowy zakres obserwowanych nieprawidłowości i brak piśmiennictwa (przede wszystkim kazuistyki) na temat postępowania logopedycznego w przypadku tej jednostki chorobowej wymagał szczególnego zindywidualizowania podejścia zarówno w zakresie działań diagnostycznych, jak i planowania oraz wdrażania założeń terapeutycznych. $\mathrm{Z}$ tego powodu możliwość przewidzenia efektów terapii i tempa oczekiwanych zmian była bardzo ograniczona. Początkowy stan mowy pacjenta (wiek 3,9) wskazywał na duże, ok. 20-miesięczne, opóźnienie rozwoju mowy dotyczące tylko mowy czynnej. Po 1,5 roku prowadzenia terapii poziom rozwoju językowego (z wyłączeniem podsystemu fonetycznego-fonologicznego) pacjenta nie odbiegał już od norm ustalonych dla dzieci polskojęzycznych w tym wieku. Artykulacja natomiast pozostawała znacząco i w nietypowym dla wieku rozwojowego zakresie zaburzona, co wymagało dalszych zintensyfikowanych i silnie zindywidualizowanych działań terapeutycznych.

Słowa kluczowe: zespół wrodzonej centralnej hipowentylacji • tracheostomia • terapia logopedyczna • rozwój mowy
\end{abstract}

\begin{abstract}
The paper presents a case study of a patient (age 5.2) with congenital central hypoventilation syndrome (CCHS) and tracheostomy. Its aim is to discuss the child's speech development and speech therapy. The presented case due to the rare disease, unusual range of observed abnormalities and the lack of literature (mainly casuistry) required a special individual approach both in the field of diagnostics as well as planning and implementation of the therapy. For this reason, the ability to predict effects of the therapy and the pace of expected changes was significantly reduced. The initial state of patient's speech (age 3.9) showed significant approx. 20-month delay but only in the field of speech production. After 1.5 year of therapy the patient's language development level (excluding the phonetic-phonological subsystem) did not differ from the standards established for Polish speaking children. Articulation, however, remained significantly and atypically impaired at this stage of development, what required further intensified and strongly individualized therapy.
\end{abstract}

Key words: congenital central hypoventilation syndrome $\bullet$ tracheostomy $\bullet$ speech therapy $\bullet$ speech and language development

Adres autora: Karolina Samsonowicz, Instytut Fizjologii i Patologii Słuchu, ul. Mochnackiego 10, 01-943 Warszawa, e-mail: k.samsonowicz@ifps.org.pl 


\section{Opis jednostki chorobowej}

Zespół wrodzonej centralnej hipowentylacji (CCHS), nazywany potocznie klątwą Ondyny, to rzadka, genetycznie uwarunkowana choroba charakteryzująca się upośledzoną kontrolą oddychania, która związana jest z dysfunkcją autonomicznego układu nerwowego [1-4]. Objawia się ona hipowentylacją najczęściej podczas snu - przede wszystkim w fazie NREM (ang. non-rapid eye movement) i nieobecną lub ograniczoną odpowiedzią oddechową na trwałą hiperkapnię i hipoksemię zarówno podczas snu, jak i czuwania [2-5]. Nazwa „klątwa Ondyny” wywodzi się z germańskiej legendy, w której to nimfa Ondyna przeklęła swojego niewiernego męża - śmiertelnika, pozbawiając jego organizm wszystkich automatycznych funkcji. Zaklęty przez Ondynę musiał cały czas pamiętać o swoim oddechu, świadomie wdychać i wydychać powietrze, w przeciwnym wypadku nieuchronnie by umarł [6]. Choroba ma charakter wrodzony, diagnoza najczęściej stawiana jest w krótkim czasie po urodzeniu [3], po uprzednim wykluczeniu chorób płuc, serca i schorzeń nerwowo-mięśniowych oraz uszkodzenia pnia mózgu mogących powodować hipowentylację $[4,5,7]$. Według kryteriów podawanych przez American Thoratic Society (ATS), aby móc zdiagnozować CCHS, należy stwierdzić mutację w obrębie genu $P H O X 2 B$ [5]. ATS podaje, że w 2009 r. na świecie zdiagnozowanych było 1000 osób z CCHS, u których stwierdzono mutację genu PHOX2B [5]. W Polsce, wg informacji udostępnianych poprzez Polską Fundację CCHS „Zdejmij klątwę", odnotowanych jest 18 przypadków tej choroby (stan na maj 2016 r.) [8]. Podstawą opieki nad pacjentami z CCHS jest dożywotnia konieczność wspomagania wentylacji w zależności od nasilenia objawów: w czasie snu lub w czasie snu i czuwania [5]. Metody domowej wentylacji obejmują m.in.: wentylację za pomocą przenośnych respiratorów na dodatnie ciśnienie podłączanych przez rurkę tracheostomijną (ang. portable positive pressure ventilator via tracheostomy), wentylację nieinwazyjną za pomocą maski nosowej lub ustno-nosowej, wszczepienie stymulatorów/rozruszników przepony (ang. diaphagram pacing) $[5,6]$. Sposób wentylacji dobierany jest indywidualnie do stanu i potrzeb pacjenta. Najpowszechniej stosowaną metodą, szczególnie w przypadku noworodków i dzieci w wieku przedszkolnym, jest wentylacja za pomocą respiratora poprzez tracheostomię. U znacznej grupy pacjentów - m.in. właśnie ze względu na długotrwałą, wykonaną w okresie niemowlęcym tracheostomię - notuje się opóźnienia/zaburzenia w rozwoju mowy [1,9]. Mimo tego nie ma opracowanych standardów postępowania logopedycznego w zakresie rehabilitacji mowy pacjentów z CCHS. W każdym przypadku rehabilitacja powinna więc być indywidualnie dostosowana do możliwości i stanu ogólnego pacjenta.

\section{Wstęp}

Celem pracy jest przedstawienie przypadku dziecka z CCHS z tracheostomią pod kątem jego rozwoju mowy oraz omówienie założeń i efektów rehabilitacji logopedycznej prowadzonej w Klinice Rehabilitacji Instytutu Fizjologii i Patologii Słuchu (IFPS) w Warszawie.

Omawiany pacjent to chłopiec urodzony o czasie z prawidłowo przebiegającej ciąży. Trudności $\mathrm{z}$ wentylacją pojawily się u niego zaraz po urodzeniu. Badanie genetyczne potwierdziło mutację genu $\mathrm{PHOX} 2 \mathrm{~B}$. Zabieg tracheotomii wykonano ok. 1,5 miesiąca po urodzeniu. Od tamtej pory chłopiec wymaga stałej wentylacji w czasie snu. W czasie czuwania oddycha samodzielnie, jednakże do spłycenia oddechu może również dochodzić w czasie obniżonej aktywności - jazdy samochodem, oglądania telewizji, słuchania bajek oraz w stanie zmęczenia. W takich sytuacjach należy monitorować saturację krwi za pomocą pulsoksymetru. W przypadku spadku saturacji poniżej 94\%, należy przypominać dziecku o oddychaniu, pobudzać je do aktywności. Jeżeli wynik nie poprawia się, pacjent powinien zostać podłączony do respiratora bądź przewentylowany workiem ambu. W czasie silnej infekcji chłopiec musi być wentylowany $24 \mathrm{~h}$ na dobę. We wrześniu 2015 roku pacjent, mając 4 lata 8 miesięcy, został poddany operacji wszczepienia stymulatora przepony firmy Avery w szwedzkim University Childrens Hospital (Akademiska Sjukhuset) w Uppsali. Jest on tym samym pierwszym i jedynym dotychczas pacjentem w Polsce użytkującym tego typu urządzenie. Około 1,5 miesiąca po operacji urządzenie zostało uruchomione $\mathrm{w}$ warunkach domowych. Po 3 nocach bezproblemowego użytkowania pacjent musiał powrócić do wentylacji poprzez tracheostomię ze względu na awarię lewego odbiornika. Pacjent został poddany udanej reoperacji w wieku 5 lat 2 miesięcy i aktualnie $\mathrm{z}$ powodzeniem użytkuje wszczepione urządzenie. Następnym oczekiwanym działaniem był zabieg dekaniulacji. Początkowo rozwój motoryczny dziecka był opóźniony o około pół roku. Zostało u niego stwierdzone obniżone napięcie mięśniowe. W badaniach neurologicznych EEG i MRI uzyskał wyniki prawidłowe. Rozwój funkcji prelingwalnych związanych z poborem pokarmu, a konstytuujących ruchową bazę dla mowy, przebiegał z nieznacznym opóźnieniem. U dziecka nie stwierdzono dysfagii, która w przebiegu CCHS jest częstym zaburzeniem towarzyszącym. Pacjent przez pierwsze 2 miesiące był karmiony przez sondę dożołądkową, równocześnie matka prowadziła trening odruchu ssania. W 3. miesiącu życia dziecko zaczęło samodzielnie ssać pierś. Kolejne sprawności związane $\mathrm{z}$ funkcją pobierania pokarmu: jedzenie łyżeczką, picie z kubka, gryzienie oraz żucie pacjent osiągał w oczekiwanych granicach czasowych bądź z około 2-miesięcznym przesunięciem czasowym. Rozwój mowy od początku przebiegał w sposób zaburzony. Przez pierwsze 2 lata życia chłopiec nie wydawał prawie żadnych dźwięków, nie wokalizował, bezgłośnie płakał. Pojedyncze nieartykułowane dźwięki pojawiały się przypadkowo i sporadycznie, a następnie zanikały. Lekarze nadzorujący stan pacjenta nie wyrazili zgody na wprowadzenie rurki fenestracyjnej ( $\mathrm{z}$ otworem) ułatwiającej wokalizację. Podejmowano natomiast próby wprowadzenia zastawki mowy (ang. speaking valve) Orator, którą pacjent ostatecznie zaakceptował i zaczął się posługiwać w wieku 2 lat, stopniowo zwiększając czas jej użytkowania w ciągu dnia. Wtedy też pojawiły się pierwsze wokalizacje: początkowo dźwięk przypominający samogłoskę [a], następnie dźwięczne artykulacje sylab z głoskami dwuwargowymi, aż w końcu w wieku 2 lat i 7 miesięcy pierwsze znaczące wyrazy. Pacjent poddany był rehabilitacji mowy od wieku 2 lat 9 miesięcy w ośrodku wczesnego wspomagania rozwoju. Równolegle do ćwiczeń mających na celu kształtowanie mowy werbalnej wprowadzano elementy komunikacji wspomagającej i alternatywnej (AAC): początkowo 
była to książka komunikacyjna umożliwiająca porozumiewanie się za pomocą znaków graficznych (zdjęcia, obrazki), następnie pojedyncze gesty systemu Makaton - chętniej stosowane przez omawianego pacjenta w codziennych, naturalnych sytuacjach dialogowych.

\section{Opis przypadku}

Pacjent po raz pierwszy trafił do IFPS w wieku 3 lat 6 miesięcy. Został skierowany do Poradni Audiologiczno-Foniatrycznej w celu dokonania kontrolnej oceny narządu słuchu. Wyniki badań otoemisji akustycznej TEOAE oraz audiometrii impedancyjnej były prawidłowe. Pacjenta przekierowano do dalszej diagnostyki w Klinice Rehabilitacji IFPS w celu dokonania oceny rozwoju mowy oraz rozwoju poznawczego i podjęcia ewentualnej terapii.

Pierwsza ocena rozwoju mowy przeprowadzona przez logopedę miała miejsce, gdy pacjent miał 3 lata 9 miesięcy. Szczątkowo rozwinięta komunikacja werbalna stanowiła utrudnienie w zastosowaniu typowych procedur diagnostycznych. Także ze względu na brak w ówczesnym czasie standaryzowanego narzędzia do badania rozwoju językowego (posiadający normy Test Rozwoju Językowego był wówczas jeszcze niedostępy w praktyce klinicznej, poza tym test ten jest przeznaczony dla dzieci powyżej 4 lat) ocena opierała się głównie na obserwacji oraz próbach diagnostycznych interpretowanych przez logopedę. Minimalny zasób leksykalny był przeszkodą w ocenie artykulacji jakimkolwiek testem artykulacyjnym. Dziecko nie byłoby w stanie samodzielnie nazwać ani nawet powtórzyć większości wyrazów stanowiących materiał językowy służący do badania artykulacji w dostępnych testach, co nie musiałoby jednak oznaczać, że badana głoska nie znajduje się w jego inwentarzu fonetycznym. Użycie testu nie oddałoby więc realnego stanu rzeczy. Ocena artykulacji opierała się na obserwacji mowy czynnej pacjenta w sytuacjach spontanicznych oraz modelowanych próbach klinicznych (m.in. powtarzaniu samogłosek i sylab). Pacjent na tym etapie badania posługiwał się w mowie czynnej około 30 wyrazami - głównie rzeczownikami o prostej budowie fonetycznej. Ze względu na bardzo liczne zniekształcenia artykulacyjne mowa dziecka nie mogła być zrozumiała bez podpowiedzi sytuacyjnej lub dla osób spoza najbliższego otoczenia. Chłopiec wspierał komunikację środkami niewerbalnymi - głównie gestami, mimiką. Pod względem rozwoju morfosyntaktycznego pacjent wkraczał w etap łączenia wyrazów w proste dwuwyrazowe wypowiedzi, pozbawione w większości końcówek fleksyjnych (choć $\mathrm{z}$ uwidaczniającym się początkiem rozwoju fleksji). Jest to etap, który dziecko o typowym rozwoju osiąga zazwyczaj do wieku 2 lat [10-12]. Można więc ogólnie stwierdzić, że opóźnienie w rozwoju mowy czynnej pacjenta na tym etapie wynosiło ok. 20 miesięcy. Pacjent wykazywał się jednak bardzo dobrym rozumieniem poleceń słownych zarówno prostych jak i złożonych oraz pojedynczych leksemów reprezentujących różne części mowy, co pozwoliło wysnuć wniosek, że opóźnienie dotyczyło tylko ekspresji mowy. Pod względem rozwoju systemu fonetyczno-fonologicznego w mowie dziecka na tym etapie wg najpowszechniej przyjętych norm artykulacyjnych powinny się pojawić głoski będące realizacjami większości fonemów systemu języka polskiego (oprócz głosek dentalizowanych szeregu zębowego oraz dziąsłowego, a także głoski [r]) [13]. W przypadku badanego pacjenta czynny inwentarz dźwięków mowy był szczątkowo rozwinięty, prawidłowo realizowanych było zaledwie kilka głosek: niektóre samogłoski ([a], [e], [y]) i kilka spółgłosek ([k], [g], [p], [b], [l]), przy czym realizacja cechy dźwięczności w przypadku spółgłosek dźwięcznych właściwych [g], [b] często była niepełna. Pozostałe dźwięki były albo zastępowane głoskami z dostępnego inwentarza dźwięków mowy (substytucja) w sposób niestały, kombinowany, najczęściej uwarunkowany sąsiedztwem fonetycznym (asymilacja) albo też pomijane (elizja), bądź zniekształcane (deformacja). W miejsca niektórych głosek pojawiały się także dźwięki niebędące dźwiękami mowy, powstałe poprzez ruchy organów niebiorących czynnego udziału w kształtowaniu miejsca artykulacji (np. samogłoska [i] realizowana była jako zwarcie gardłowe). Brak samogłosek ([i], [o], [u]) był wyjątkowo rzadko spotykaną nieprawidłowością u dziecka w tym wieku. Także zaburzenie rezonansu nosowego, utrzymujące się jeszcze przez następne 1,5 roku, było bardzo nietypowym zjawiskiem. Pacjent mimo prawidłowej budowy jamy nosowej i gardła oraz braku zaburzeń ruchomości podniebienia miękkiego nie był w stanie realizować głosek nosowych - przede wszystkim spółgłoski [m] (substytucja na spółgłoski dwuwargowe ustne [p], [b]), która jest jedną z pierwszych głosek pojawiających się w mowie dziecka, jej wymowa jest łatwa i niezwykle rzadko stanowi problem u dzieci. Spółgłoska nosowa [n] była najczęściej pomijana lub substytuowana na [1], gdyż pacjent nie realizował w ogóle głosek przedniojęzykowo-zębowych. Ogólnie można stwierdzić, że deformacja struktury fonetyczno-fonologicznej oraz morfologicznej wyrazów w mowie pacjenta była na tyle głęboka, że najczęściej niemożliwe było ustalenie zachodzących w nich patologicznych zjawisk. Głos dziecka w subiektywnej, orientacyjnej ocenie odsłuchowej był dźwięczny, ale stosunkowo cichy, niski, ochrypnięty, tworzony jednak bez większego wysiłku. Stwierdzono także niską sprawność artykulacyjną: małą ruchomość warg i języka, ich obniżone napięcie mięśniowe, niską precyzję i zakres wykonywanych ruchów artykulacyjnych, a także obniżoną umiejętność dokonywania ruchów celowych i kontrolowanych (praksja oralna). W budowie aparatu artykulacyjnego stwierdzono brak wyraźnego apexu języka, poza tym nie zaobserwowano znaczących odchyleń. Równolegle do oceny rozwoju mowy dokonano oceny rozwoju poznawczego pacjenta, aby m.in. ustalić odpowiednie cele dalszej terapii. Chłopiec został przebadany przez psychologa Międzynarodowa Wykonaniowa Skala Leitera P-93 i uzyskał wynik równy 15 punktów. Z prawdopodobieństwem 85-proc. jego wynik prawdziwy mieścił się w przedziale $122-140$ punktów w skali ilorazów wechslerowskich, leżał więc w obszarze wyników wysokich i bardzo wysokich. W dalszym przebiegu ewaluacji stanu zdrowia pacjenta dokonano także oceny foniatrycznej za pomocą badania laryngosokopowego, które nie wykazało nieprawidłowości w budowie i funkcjonowaniu narządu głosu.

W okresie omawianym w niniejszej pracy pacjent uczęszczał przez 17 miesięcy na indywidualne zajęcia logopedyczne w Klinice Rehabilitacji IFPS z częstotliwością minimum 1 godzina w tygodniu (aktualnie kontynuuje terapię) oraz przez 10 miesięcy na terapię psychomotoryczną prowadzoną w grupie ok. 5 dzieci. Dodatkowo pacjent został poddany serii 10 zabiegów fizjoterapeutycznych elektrostymulacji 
obwodowego narządu mowy obejmujących mięśnie języka, warg i podniebienia miękkiego. Równolegle do terapii prowadzonej w Klinice Rehabilitacji IFPS chłopiec uczęszczał na zajęcia $\mathrm{z}$ logopedą w przedszkolu i objęty był rehabilitacją ruchową poza IFPS. Przez cały omawiany okres pacjent miał rurkę tracheostomijną.

Dobór metod terapeutycznych opierał się na analizie informacji uzyskanych z poszczególnych elementów diagnozy przy równoczesnym braku standardów postępowania logopedycznego w przypadku CCHS oraz braku możliwości porównania omawianego przypadku dziecka $\mathrm{z}$ danymi z piśmiennictwa na ten temat (także w zakresie kazuistyki). Za podstawowy cel terapii logopedycznej na tym etapie obrano stymulowanie rozwoju komunikacji werbalnej - usprawnianie rozwoju mowy przede wszystkim w zakresie czynności realizacyjnych (produkcja mowy). Nie zdecydowano się na kontynuację pracy alternatywnymi i wspomagającymi metodami komunikacji ze względu na zadowalające rokowania odnośnie dalszego kształtowania mowy werbalnej. Do takiego pozytywnego oglądu przyczyniały się następujące czynniki: prawidłowy rozwój poznawczy pacjenta, prawidłowe funkcjonowanie narządu słuchu, brak jednoznacznych uszkodzeń neurologicznych i niedowładów, brak uszkodzenia fałdów głosowych i możliwość fonacji, pojawienie się pierwszych artykułowanych realizacji słownych, dobre rozumienie mowy a także odpowiednia motywacja i wsparcie ze strony rodziców, jak i perspektywa dekaniulacji. Podstawowe grupy ćwiczeń obejmowały m.in.: ćwiczenia oddechowo-fonacyjne (w tym rozwijanie świadomości związanej z czynnością układu oddechowego w spoczynku i podczas tworzenia głosu, praca nad elementami cech głosu zależnymi od czynności układu oddechowego, ćwiczenia kształtujące poszczególne cechy głosu [14], ćwiczenia usprawniające pracę aparatu artykulacyjnego - warg, języka, podniebienia miękkiego, ćwiczenia sprawności językowych: fleksyjne, składniowe, leksykalne, słowotwórcze, artykulacyjne, ćwiczenia słuchu fonemowego i fonetycznego (jako konieczne do kształtowania prawidłowej artykulacji), ćwiczenia sprawności komunikacyjnych, a także dodatkowo, jako towarzyszące stymulacji mowy, ćwiczenia ogólnorozwojowe i wspierające funkcje poznawcze m.in. pamięć (słuchowa i wzrokową), myślenie przyczynowo-skutkowe, kategoryzację, myślenie przez analogię. Kształtowanie początków komunikacji językowej odbywało się za pomocą techniki programowania języka, zakładającej wprowadzanie struktur językowych w odpowiedniej, rozwojowej kolejności, minimalizację gramatyki i zasobu leksykalnego, czyli budowanie dla dziecka uproszczonego środowiska językowego, biorącego pod uwagę jego problemy komunikacyjne. Znaczącym wsparciem było wprowadzenie od samego początku rehabilitacji pacjenta nauki czytania na bazie założeń Symultaniczno-Sekwencyjnej Nauki Czytania: Nauka czytania była nie tyle celem, co środkiem do opanowania systemu językowego w mowie czynnej [15], w tym także kształtowania podsystemu fonetyczno-fonologicznego, gdzie początkowe działania terapeutyczne opierały się na wywołaniu samogłosek i prymarnych sylab przy równoczesnym wprowadzeniu liter. W efekcie prowadzonej terapii już po upływie 1 roku pacjent bez trudu potrafił czytać ze zrozumieniem teksty złożone ze zdań wielowyrazowych, co szło w parze z coraz sprawniejszym posługiwaniem się językiem w mowie spontanicznej. Inną techniką, która od początku towarzyszyła terapii, było prowadzenie pamiętnika, który spełniał m.in. rolę materiału językowego, był sposobem na poszerzanie zasobu słownictwa i uczenia reguł odmiany fleksyjnej, składni zdań, miał za zadanie prowokować do używania języka dźwiękowego, prowadzenia dialogu, a w dalszej kolejności aktywnego zadawania pytań i tworzenia prostych narracji, stwarzał także okazję do ćwiczeń czytania według założeń przyjętych w terapii $[15,16]$. Równolegle do zajęć logopedycznych pacjent uczęszczał na terapię psychomotoryczną, wg modelu belgijskiego opracowanego przez Marcelle Procus oraz Michele Block, będącą systemem usprawniania dzieci w wieku przedszkolnym i wczesnoszkolnym (3-10 r.ż.) z objawami dysharmonii rozwojowej [17]. W wymiarze klinicznym celem terapii psychomotorycznej jest likwidowanie różnego rodzaju nieprawidłowości i zaburzeń m.in.: ruchu, koordynacji wzrokowo-ruchowej, mowy, zachowania, emocji, pamięci, uwagi. Celem terapii w przypadku omawianego dziecka była dodatkowa stymulacja rozwoju mowy czynnej poprzez wzajemne usprawnianie czynności ruchowych i funkcji mowy oraz ich utrwalanie poprzez powtarzanie [17]. Dodatkowym celem niewynikającym bezpośrednio z diagnozy psychologicznej (nie był to zakres działań przeprowadzonych przez psychologa), zaś z relacji rodziców oraz obserwacji dziecka, było polepszenie psychofizycznego i społecznego funkcjonowania pacjenta, tak by mimo obecności rurki tracheotomijnej mógł on budować poczucie własnej wartości w grupie rówieśników.

Po ukończeniu 5 lat pacjent został poddany ponownej ocenie rozwoju mowy. W efekcie terapii komunikacja werbalna rozwinęła się na tyle, że możliwe było wykonanie testów językowych w celu uzyskania poglądu na temat efektywności prowadzonej terapii, ustalenia dalszego postępowania logopedycznego, jak też odniesienia uzyskanych wyników do grupy rówieśniczej, aby móc udzielić informacji rodzicom na temat postępów dziecka. Tym razem pacjent mógł zostać przebadany za pomocą standaryzowanych narzędzi: Testu Rozwoju Językowego (TRJ) [18] oraz 100-wyrazowego Testu Artykulacyjnego [19]. Ze względu na brak możliwości zastosowania tych samych narzędzi badawczych przed rozpoczęciem terapii i po niej, porównanie stanu mowy pacjenta sprzed i po terapii w założeniu miało

Tabela 1. Interpretacja wyników TRJ na skali staninowej [18] Table 1. Interpretation of TRJ results on the stanine scale [18]

\begin{tabular}{|c|c|c|}
\hline STANIN & INTERPRETACJA & $\begin{array}{l}\text { UPROSZCZONA } \\
\text { INTERPRETACJA }\end{array}$ \\
\hline 1 & Wynik najniższy & \multirow{3}{*}{ Wynik niski } \\
\hline 2 & Wynik bardzo niski & \\
\hline 3 & Wynik niski & \\
\hline 4 & Wynik średni niższy & \multirow{3}{*}{ Wynik typowy } \\
\hline 5 & Wynik średni & \\
\hline 6 & Wynik średni - wyższy & \\
\hline 7 & Wynik wysoki & \multirow{3}{*}{ Wynik wysoki } \\
\hline 8 & Wynik bardzo wysoki & \\
\hline 9 & Wynik najwyższy & \\
\hline
\end{tabular}


służyć głównie wymienionym powyżej celom klinicznym, nie zaś celom badawczym; jego analiza w niniejszym artykule jest retrospekcyjna.

W momencie przeprowadzenia badania TRJ wiek pacjenta wynosił 5 lat 1 miesiąc. Normy TRJ zostały opracowane na podstawie wyników dzieci o typowym rozwoju, więc wynik testu pozwala ocenić, w jakim stopniu badany przypadek kliniczny zbliżony jest pod względem rozwoju językowego do typowo rozwijających się dzieci. Test pozwala na ocenę kompetencji dziecka w zakresie czynnego i biernego zasobu słownika, rozumienia i używania konstrukcji gramatycznych oraz rozumienia słyszanego tekstu. Nie uwzględnia płaszczyzny fonologicznej języka. Zdecydowano się interpretować wyniki wyliczone dla norm ogólnych (możliwe jest także odniesienie się do norm dla płci). Przedział ufności, w jakim mieści się wynik prawdziwy badanego pacjenta, określono dla prawdopodobieństwa równego 85\%. Wyliczone przedziałowe wyniki surowe odniesiono do norm staninowych, których interpretację przedstawia tabela 1 [18].

Pacjent osiągnął w poszczególnych podtestach następujące wyniki (tabela 2):

- Słownik - rozumienie słów: stanin 3,

- Słownik - produkcja słów: stanin 6,

- Gramatyka - rozumienie zdań (ocena rozumienia konstrukcji składniowych): stanin 6,

- Gramatyka - powtarzanie zdań (ocena rozwoju morfosyntaktycznego dziecka): stanin 7 ,

- Gramatyka - odmiana wyrazów (ocena kompetencji w zakresie przyswojenia reguł fleksyjnych języka): stanin 5,

- Dyskurs - rozumienie tekstów (ocena rozumienia usłyszanego przed chwilą tekstu): stanin 4 (wyniku tego podtestu nie wlicza się do wyniku ogólnego).

Tabela 2. Wyniki znormalizowane TRJ obliczane wg norm ogólnych

Table 2. Standardized results TRJ calculated according to general norms

\begin{tabular}{|c|c|c|c|c|}
\hline & ROZUMIENIE & PRODUKCJA & SUMA & STANIN \\
\hline \multirow[t]{2}{*}{ SŁOWNIK } & $\begin{array}{l}\text { 1. ROZUMIENIE SŁÓW } \\
\text { (STANIN) }\end{array}$ & $\begin{array}{l}\text { 3. PRODUKCJA StÓW } \\
\text { (STANIN) }\end{array}$ & $\begin{array}{l}\text { StOWNIK WYNIK } \\
\text { PRZELICZONY }(1+3)\end{array}$ & SŁOWNIK STANIN \\
\hline & 3 & 6 & 9 & 5 \\
\hline \multirow{4}{*}{ GRAMATYKA } & \multirow[b]{2}{*}{$\begin{array}{l}\text { 4. ROZUMIENIE ZDAŃ } \\
\text { (STANIN) }\end{array}$} & $\begin{array}{l}\text { 2.POWTARZANIE ZDAŃ } \\
\text { (STANIN) }\end{array}$ & \multirow{4}{*}{$\begin{array}{c}\text { GRAMATYKA WYNIK } \\
\text { PRZELICZONY }(4+2+5) \\
\mathbf{1 8}\end{array}$} & \\
\hline & & 7 & & GRAMATYKA STANIN \\
\hline & 6 & $\begin{array}{l}\text { 5. ODMIANA WYRAZÓW } \\
\text { (STANIN) }\end{array}$ & & 6 \\
\hline & & 5 & & \\
\hline \multirow[t]{2}{*}{ SUMA } & $\begin{array}{l}\text { ROZUMIENIE WYNIK } \\
\text { PRZELICZONY }(1+4)\end{array}$ & $\begin{array}{l}\text { PRODUKCJA WYNIK } \\
\text { PRZELICZONY }(3+2+5)\end{array}$ & $\begin{array}{c}\text { WYNIK OGÓLNY } \\
\text { PRZELICZONY } \\
(1+2+3+4+5)\end{array}$ & \\
\hline & 9 & 18 & 27 & \\
\hline \multirow{2}{*}{ STANIN } & ROZUMIENIE STANIN & PRODUKCJA STANIN & & WYNIK OGÓLNY STANIN \\
\hline & 5 & 6 & & 6 \\
\hline
\end{tabular}

Tabela 3. Wyniki TRJ dla podtestów wraz z przedziałami ufności

Table 3. TRJ results for sub-tests with confidence intervals

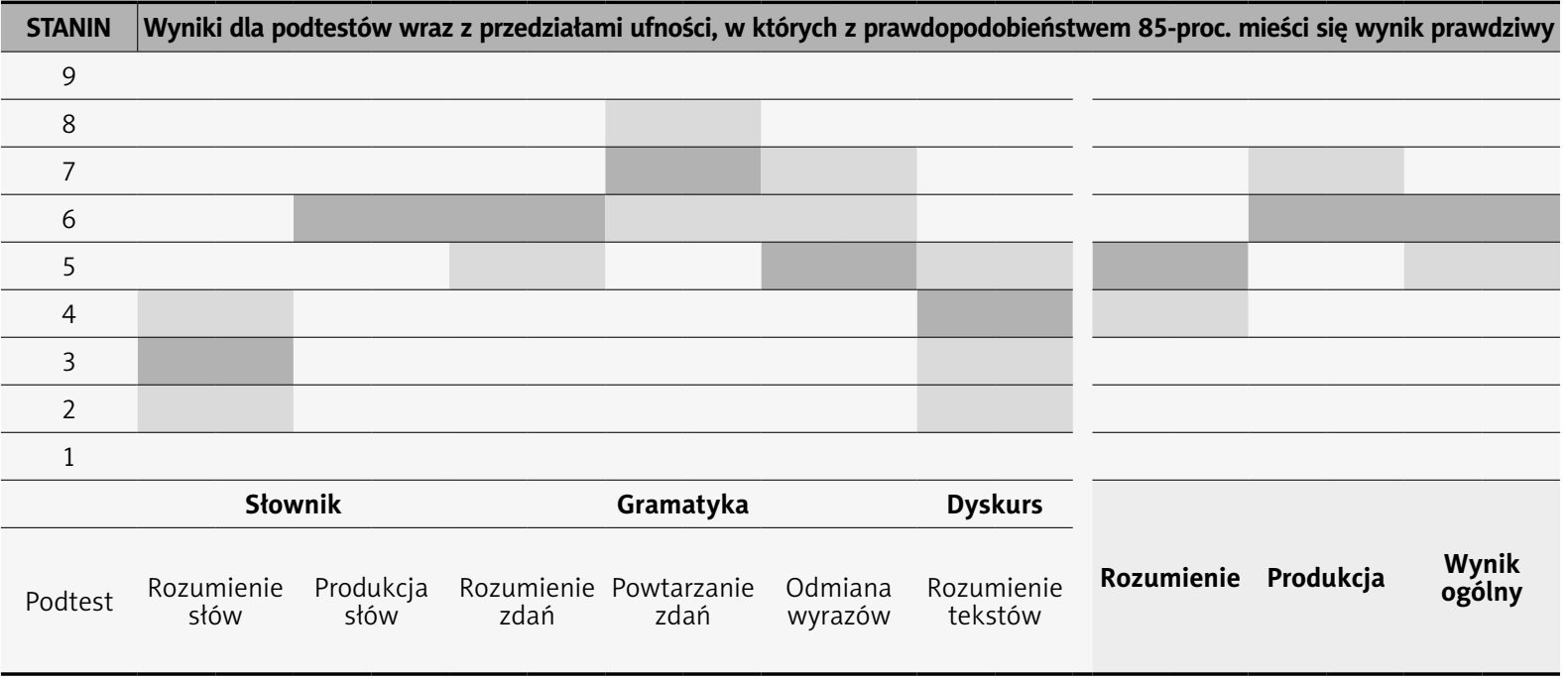


Wynik dla poszczególnych podskal są następujące:

- Słownik: stanin 5,

- Gramatyka: stanin 6,

- Rozumienie: stanin 5,

- Produkcja: stanin 6.

Wynik ogólny chłopca odpowiada staninowi 6 . Wyniki staninowe poszczególnych podtestów uzupełnione o przedziały ufności umożliwiające określenie, między jakimi wartościami z prawdopodobieństwem 85-proc. mieści się wynik prawdziwy badanego pacjenta, ilustruje tabela 3., zaś wyniki poszczególnych podskal wraz z przedziałami ufności i ich interpretacją przedstawia tabela 4 .

Tabela 4. Wyniki poszczególnych podskal TRJ wraz z przedziatami ufności i ich interpretacją

Table 4. Results of individual TRJ subscales with confidence intervals and their interpretation

\begin{tabular}{|c|c|c|}
\hline STANIN & $\begin{array}{c}\text { WYNIK } \\
\text { STANINOWY }\end{array}$ & INTERPRETACJA \\
\hline ROZUMIENIE & $4-5$ & $\begin{array}{l}\text { Wynik średni niższy } \\
\text { - średni }\end{array}$ \\
\hline PRODUKCJA & $6-7$ & $\begin{array}{c}\text { Wynik średni wyższy } \\
- \text { wysoki }\end{array}$ \\
\hline SŁOWNIK & $4-5$ & $\begin{array}{c}\text { Wynik średni niższy } \\
\text { - średni }\end{array}$ \\
\hline GRAMATYKA & $6-7$ & $\begin{array}{c}\text { Wynik średni wyższy } \\
- \text { wysoki }\end{array}$ \\
\hline WYNIK OGÓLNY & $5-6$ & $\begin{array}{c}\text { Wynik średni } \\
\text { - wynik średni wyższy }\end{array}$ \\
\hline
\end{tabular}

Z prawdopodobieństwem 85-proc. wynik ogólny pacjenta leży w obszarze wyników średnich oraz średnich wyższych, są to wyniki typowe dla populacji dzieci w przedziale wiekowym 5,0-5,5. Chłopiec lepiej poradził sobie z zadaniami z zakresu produkcji niż rozumienia, lepiej też wykonał zadania dotyczące gramatyki niż słownictwa. Wynik podskali produkcji mieszczący się w obszarze wyników średnich - wyższych oraz wysokich sugeruje, że pacjent nieco lepiej niż jego rówieśnicy radzi sobie w zakresie produkcji słów lub zdań. Podobnie wynik podskali gramatyki może sugerować, że poziom zarówno rozumienia konstrukcji składniowych, jak i ich tworzenia, a także znajomość reguł odmiany fleksyjnej są na wyższym niż przeciętny poziomie, co oznacza dobry rozwój kompetencji morfosyntaktycznych. Wyniki podskal rozumienia oraz słownika mieszczą się w obszarze wyników typowych i odpowiadają przedziałowi wyników średnich niższych i średnich. Można więc wnioskować, że kompetencje pacjenta $\mathrm{z}$ zakresie rozumienia i produkcji mowy nieznacznie się różnią na korzyść produkcji, a w zakresie gramatyki i słownika na korzyść gramatyki. Dla wyniku ogólnego sprawdzono także wyniki centylowe. Uzyskany przez pacjenta wynik odpowiada 81 centylowi, co oznacza, że $81 \%$ dzieci osiąga wyniki niższe lub równe temu wynikowi. Przy uwzględnieniu przedziałów ufności, można stwierdzić, że z 85-proc. prawdopodobieństwem wynik prawdziwy pacjenta mieści się w przedziale od 77 do 86 centyla.

Do badania artykulacji użyto 100-wyrazowego Testu Artykulacyjnego, który jest wystandaryzowanym narzędziem do oceny realizacji systemu spółgłoskowego języka polskiego dzieci w wieku 3,0-7,3 r.ż. Ocena wypowiedzi przeprowadzana jest wyłącznie w skali dychotomicznej: prawidłowe - nieprawidłowe (1 punkt - 0 punktów). Każda niewłaściwa realizacja fonetyczna: deformacja, substytucja lub elizja danego elementu fonetycznego skutkuje nieprzyznaniem punktu. W momencie przeprowadzenia badania wiek pacjenta wynosił 5 lat 2 miesiące. Pacjent uzyskał wynik surowy 149 punktów. Wynik ten nie znajduje odpowiednika na skali stenowej dotyczącej norm dla dzieci w wieku $5,0-5,11$, która rozpoczyna się od 160 punktów. Wynik pacjenta jest więc bez wątpienia wynikiem poniżej normy dla przedziału wiekowego, znajduje się także poniżej obszaru wyników traktowanych jako niskie. Badanie 100-wyrazowym Testem Artykulacyjnym przedstawia wynik wyłącznie ilościowy - obrazuje stopień, w jakim wymowa pacjenta odbiega od wymowy większości jego rówieśników. W celu ustalenia odpowiedniego kierunku terapii konieczna była równoległa analiza jakościowa (na bazie materiału językowego z ww. testu). Nieprawidłowości artykulacyjne u badanego pacjenta dotyczyły zarówno samogłosek, jak i spółgłosek. Samogłoska [o] była najczęściej substytuowana przez samogłoskę [a]. Samogłoska [i] najczęściej realizowana była prawidłowo, choć niekiedy zdarzała się substytucja na [y] lub dźwięk niesystemowy, zbliżony do dźwięków gardłowych. Półsamogłoska [i] była najczęściej substytuowana przez spółgłoskę [l] - także w przypadku wymowy spółgłosek miękkich wargowych, gdzie dochodzi do zjawiska palatalności asynchronicznej. Spółgłoski przedniojęzykowo-zębowe [t, d, n] były substytuowane przez spółgłoski tylnojęzykowe [k, g]. Brak było spółgłoski prepalatalnej nosowej [ń], w miejsce której pojawiały się zmienne substytucje, najczęściej zależne od sąsiedztwa fonetycznego (asymilacja). Zaburzona była cecha dźwięczności spółgłosek dźwięcznych właściwych (najczęściej realizowana w sposób niepełny). Głoski prepalatalne [ś, ź, ć, 3́] były deformowane, w czasie artykulacji powietrze przepływało torem bocznym, nie zaś w środkowej części języka. Głoski przedniojęzykowo-zębowe [s, z, c, 3] były substytuowane przez zdeformowany szereg ciszący lub realizowane interdentalnie. Głoski przedniojęzykowo-dziąsłowe [š, ž, č, ̌̌] były substytuowane przez głoski syczące (ale interdentalnie) lub zdeformowane głoski prepalatalne. Głoska [r] była substytuowana przez [1] (norma dla wieku), a czasem pomijana. Ponowne badanie motoryki artykulacyjnej wykazało poprawę w zakresie sprawności artykulacyjnej, jednak ruchomość warg i języka, precyzja i zakres wykonywanych ruchów artykulacyjnych, a także umiejętność dokonywania ruchów celowych i kontrolowanych nie mogły zostać uznane za w pełni prawidłowe i wymagały dalszego usprawniania.

\section{Wnioski}

Początkowy stan mowy pacjenta (wiek 3,9) wskazywał na orientacyjne, ok. 20-miesięczne opóźnienie rozwoju mowy czynnej. Zarejestrowane zakłócenia obejmowały struktury językowe o różnym stopniu złożoności, przy czym obserwowane zjawiska dotyczyły wyłącznie ekspresji mowy. Po prawie 1,5-rocznej terapii poziom rozwoju językowego (z wyłączeniem podsystemu fonetycznego-fonologicznego) pacjenta nie odbiegał od norm ustalonych dla rozwoju dzieci zdrowych. Nieprawidłowości obecne u dziecka dotyczyły tylko realizacji elementarnych jednostek języka 
- dźwięków mowy, co pozwala postawić diagnozę dyslalii obwodowej wielorakiej o złożonym patomechanizmie anatomiczno-funkcjonalnym [20]. Wśród przyczyn zaburzeń realizacji fonemów jako najważniejszy patomechanizm trzeba wymienić tracheostomię, utrudniającą czy wręcz uniemożliwiającą artykulację dźwięków, a co za tym idzie - brak wczesnego treningu głosowego przygotowującego do mówienia i artykulacji dźwięków języka ojczystego i małą sprawność narządów mowy. Także obniżone napięcie mięśniowe oraz wczesne doświadczenia rozwoju czynności prymarnych, mimo iż przebiegały z nieznacznym opóźnieniem, mogły jednak prowadzić do odmienności doświadczeń konstytuujących ruchową bazę dla mowy. Poza tym w obrębie powiązanego systemu oddechowo-fonacyjno-artykulacyjnego zaburzenia na jednym poziomie mogą wpływać na pracę innych układów [21].

Po ponownej ocenie logopedycznej cele terapii zostały zmodyfikowane: ukierunkowano ją głównie na kształtowanie prawidłowej artykulacji. Kolejność wywoływania głosek powinna uwzględniać charakter rozwojowy i naśladować naturalną drogę nabywania sprawności artykulacyjnej w języku polskim. Jednak ze względu na dużą liczbę nieprawidłowo realizowanych dźwięków i nietypowość obserwowanych zjawisk należy w omawianym przypadku szczególnie zindywidualizować metodykę wywoływania głosek i tę sekwencję rozwojową na bieżąco korygować, uwzględniając m.in. równoległą pracę nad dźwiękami, które daje się łatwiej u pacjenta wywołać, oraz tymi, których wadliwa postać jest mniej utrwalona.

\section{Podsumowanie}

Diagnoza logopedyczna dziecka oraz planowanie terapii są zawsze zadaniami wymagającymi indywidualnego podejścia, jednak nabiera to szczególnego znaczenia w przypadkach chorobowych rzadko występujących i o rzadkim przebiegu. Wyjątkowość omawianego przypadku dziecka oraz nietypowy zakres obserwowanych nieprawidłowości zmusiły do szukania specyficznych i niestandardowych działań diagnostycznych oraz rozwiązań terapeutycznych. Przedstawiony przykład pacjenta z CCHS nie podlegał żadnym standardom logopedycznym, z tego powodu możliwość przewidzenia skuteczności terapii była bardzo ograniczona i niezbędna była stała weryfikacja jej założeń w trakcie prowadzonych działań.

\section{Piśmiennictwo:}

1. Vanderlaan M, Holbrook CR, Wang M, Tuell A, Gozal D. Epidemiologic survey of 196 patients with congenital central hypoventilation syndrome. Pediatr Pulmonol, 2004; 37(3): 217-29.

2. Chen ML, Keens TG. Congenital central hypoventilation syndrome: not just another rare disorder. Paediatr Respir Rev, 2004; 5(3):182-89.

3. Trang H, Dehan M, Beaufils F, Zaccaria I, Amiel J, Gaultier C. The French Congenital Central Hypoventilation Syndrome Registry: general data, phenotype, and genotype. Chest; 2005; 127(1):72-79.

4. Ramanantsoa N, Gallego J. Congenital central hypoventilation syndrome. Respir Physiol Neurobiol, 2013; 189(2): 272-79.

5. Weese-Mayer DE, Berry-Kravis EM, Ceccherini I, Keens TG, Loghmanee DA, Trang H. An Official ATS Clinical Policy Statement: Congenital Central Hypoventilation Syndrome. Genetic Basis, Diagnosis, and Management. Am J Respir Crit Care Med, 2010; 181(6): 626-44.

6. Materiały The Central Hypoventilation Syndrome European Network. Zespół ośrodkowej hipowentylacji. Broszura informacyjna dla Pacjenta i jego Opiekuna wersja 1.2 - Listopad 2012. www.ichsnetwork.eu (dostęp: maj 2016).

7. Chin WT. Congenital Central Hypoventilation Syndrome, 2014. http://emedicine.medscape.com/ (dostęp: maj 2016).

8. Materiały Polskiej Fundacji CCHS. http://zdejmijklatwe.blogspot. com/ (dostęp: luty 2016).

9. Montirosso R, Morandi F, D’Aloisio C, Berna A, Provenzi L, Borgatti R. International Classification of Functioning, Disability and Health in children with congenital central hypoventilation syndrome. Disabil Rehabil. 2009; 31 Suppl 1: 144-52.

10. Gleason JB, Ratner NB. Psycholingwistyka. Gdańsk: GWP; 2005.
11. Aichison J. Ssak, który mówi. Wstęp do psycholingwistyki. Warszawa: Państwowe Wydawnictwo Naukowe; 1991.

12. Cieszyńska J, Korendo M. Wczesna interwencja terapeutyczna. Stymulacja rozwoju dziecka od noworodka do 6. roku życia. Kraków: Wydawnictwo Edukacyjne; 2007.

13. Golanowska M. Stan polskich badań nad rozwojem artykulacji dziecka. Audiofonologia, 1996; 9: 61-88.

14. Szkiełkowska A, Kazanecka E. Emisja głosu. Wskazówki metodyczne. Warszawa: Instytut Fizjologii i Patologii Słuchu, Uniwersytet Muzyczny Fryderyka Chopina; 2011.

15. Cieszyńska-Rożek J. Metoda Krakowska wobec zaburzeń rozwoju dzieci. Z perspektywy fenomenologii, neurobiologii i językoznawstwa. Kraków: Wydawnictwo Metody Krakowskiej; 2013.

16. Szuchnik J, Skarżyński H. Uczeń - zmysły, komunikacja. Warszawa: Stowarzyszenie Przyjaciół Osób Niesłyszących i Niedosłyszących; 2004.

17. Kułakowska Z, Borkowska M, Zychowicz B. Terapia psychomotoryczna dzieci metodą Procus i Block. Warszawa: Wydawnictwo PZWL; 2012.

18. Smoczyńska M, Haman E, Czaplewska E, Maryniak A, Krajewski G, Banasik N, Kochańska M, Łuniewska M, Morstin M. Test Rozwoju Językowego. TRJ. Podręcznik. Warszawa: Instytut Badań Edukacyjnych; 2015.

19. Krajna E. 100-wyrazowy Test Artykulacyjny. Komlogo; 2008.

20. Emiluta-Rozya D: Modyfikacja zestawienia form zaburzeń mowy H. Mierzejewskiej i D. Emiluty-Rozya. W: Porajski-Pomsta J, red. Diagnoza i terapia w logopedii. Warszawa: Elipsa, 2008, s. 25-36.

21. Pluta-Wojciechowska D. Mowa dzieci z rozszczepem wargi i podniebienia. Kraków: Wydawnictwo Naukowe Uniwersytetu Pedagogicznego; 2011. 
